\title{
Development of synergistic between digitalization MSMEs and digital society in Indonesia
}

\author{
Adietya Arie Hetami ${ }^{1}$, Muhammad Fikry Aransyah ${ }^{1 *}$ \\ ${ }^{1}$ Faculty of Social and Political Sciences, Mulawarman University, Indonesia \\ ${ }^{*}$ Corresponding author: fikryaransyah@ fisip.unmul.ac.id
}

\begin{abstract}
ARTICLE INFO
ABSTRACT

DOI: $10.46223 / \mathrm{HCMCOUJS.}$ econ.en.11.2.1934.2021

Received: June $15^{\text {th }}, 2021$

Revised: July $28^{\text {th }}, 2021$

Accepted: July $31^{\text {st }}, 2021$

Keywords:

covid-19; digital MSMEs; digital society; Indonesia

This article aims to elaborate on Micro, Small, and Medium Enterprises (MSMEs) and the Digital Society during the Covid-19 pandemic in Indonesia. The Covid-19 pandemic has paralyzed most sectors of the economy, especially micro-enterprises. The profits of most MSME actors did not increase, and many went bankrupt. That is why MSME business actors change their sales strategy with digitalization schemes. The digitization scheme is to use the marketplace as an intermediary and social media as a marketing technique. In addition, digital MSME actors must synergize with the digital community in marketing products and services. Therefore, the SME digital development initiative can be an alternative to saving business actors during the Covid-19 pandemic. This article uses a literature study with a library research method approach by elaborating various literature on the development of digital SMEs. Twenty-five articles were reviewed in this study from Sinta (Science and Technology Index) and Google Scholar. The paper argues that the development of digital MSMEs has become an alternative to saving and developing digital entrepreneurship in Indonesia during the Covid-19 pandemic.
\end{abstract}

\section{Introduction}

The global Covid-19 pandemic in every country in the world has affected every area of people's lives. In Indonesia, it is influenced by almost all sectors, especially the economic ecosystem, which is the center of people's lives. The Covid-19 outbreak has also slowed down the Indonesian economic sector with its various derivatives. The MSME sector, as an essential part of the economic sector, was significantly affected. In addition, many MSMEs are currently facing various problems such as reduced sales, reduced capital, distribution difficulties, raw material difficulties, reduced production, and many layoffs of workers and employees that pose a threat to the national economy. The momentum of national economic growth and employment of MSMEs is facing a decline in productivity which causes a significant decrease in profits.

According to a Bank Indonesia survey (Saputra, 2021), 87.5\% of MSMEs were affected by the Covid-19 pandemic. Of these, about 93.2\% harmed sales (Saputra, 2021). The growth of the MSME sector also affects the country's economic growth. The Covid-19 pandemic has reduced 'people's purchasing power, and the government reduced interaction outside to prevent the spread of infectious diseases. As a result, many consumers are distancing themselves and 
turning to digital shopping. Then many SMEs have had to stop their activities due to reduced purchasing volumes and still rely on offline sales. After that, several MSME sectors that are ultimately unable to adapt to digital have a significant impact on store closures. However, the Covid-19 pandemic has indirectly brought new changes to 'Indonesia's business style. Change is the transition from an offline business to a digital business, also known as the digital startup phenomenon. As intermediaries, social media and marketplaces can be concepts that allow MSME actors to have complete marketing access (Purnomo, 2019).

MSMEs in Indonesia have become the most critical pillar in the economic ecosystem. It is also known that $99 \%$ of Indonesian business actors work in the MSME sector (KemenkopUKM, 2020). The role of MSMEs has contributed 60\% to the Gross Domestic Product (GDP) and $97 \%$ of the absorption of labor affected by the epidemic. Meanwhile, only $16 \%$ of SMEs currently participate in the digital economy ecosystem (Arianto, 2021). In addition, the marketplace offers various promotions (free shipping, cashback, discounts) to attract consumers to make purchases at online stores owned by $72 \%$ of small businesses. In addition, the marketplace is considered safe for transactions; $69 \%$ and $66 \%$ are considered easy to use or user-friendly. Second, the marketplace seems to play a role in providing adequate training to MSMEs on how to sell online, 55\% of which help them sell MSME products to the export sector. In particular, the Covid-19 pandemic has played an essential role in the marketplace by supporting the survival of MSMEs.

In Indonesia, the MSME sector is one of the main pillars of the Indonesian economy. In fact, during the 1998 economic crisis, the MSME sector was very active in maintaining the Indonesian economic ecosystem. The same applies to the time of the Covid-19 pandemic. The SME sector has excellent potential to become a driver of national economic recovery. Therefore, we need a business model that can adapt to technological advances and become the birth of the digital startup model. This business model combines digital technology and entrepreneurship to create a new and unique phenomenon in business (Giones \& Brem, 2017).

The role of digital technology in this regard has a significant impact on newly created business units. New technology models harness the potential for collaboration and collective intelligence to design and launch more robust and sustainable business initiatives. However, digital entrepreneurship has four aspects: digital actors, digital activities, digital motivation, and digital organizations (Elia, Margherita, \& Passiante, 2020).

OECD (2017) press release states that digitalization by utilizing the latest technology could be good for a 'country's business. Don Tapscott said digitization provides added value for its users (Wuryantai, 2004). However, digitization impacts its users due to boundaries previously barriers to trade (Lee, Falahat, \& Sia, 2019). Digitization also means the merging of national boundaries into a single unit. By digitizing, all regions can communicate with each other without being limited by the boundaries of their respective countries.

This digitalization is related to the theory of economic integration by Balassa (2013), namely the process of state boundaries to become a single entity in the international world, especially in the trade sector. So it can be said that actors involved in digitizing must know what is meant by digitization, the impact of digitization, and how digitization can be put to good use.

SMEs can also digitize, which is done in various ways. For example, by utilizing ecommerce to help introduce their wares to consumers. SMEs can use digitalization as a way to expand their market share to cover international markets. Thus, the author sees that digitalization for SMEs can become a boomerang if it is not used correctly by SMEs. 
Issues related to digital society are contemporary issues after the world enters the $21^{\text {st }}$ century. The world is no longer preparing for digital transformation but is already in the digital era itself. The digital society is no longer about a group in a new and unfamiliar future; it is ourselves. When asked who the definition of a digital society is, the answer is that digital technology has penetrated various aspects of our lives every day. Various digital tools have mediated our daily activities, and the goods we have are increasingly being shaped by digital intervention. Ownership of computer equipment in desktop computers, laptops, and smartphones has allowed us to carry out "cyber-activity," both at work and home (Martin, 2008).

Based on the above understanding, a digital society should be a society with digital usage skills. It is characterized by productivity, professional self and career development, and the use of digital to solve problems. This ideal level is undoubtedly very much compared to the reality that is happening in Indonesian society today. Instead of supporting productivity, selfdevelopment, and development in the community, digital technology has become a source of new problems for groups of people who are not ready to transform and have not optimized the level of digital skills.

The results of a survey by the Indonesian Internet Service Providers Association (APJII) regarding internet penetration in Indonesia in 2019 - 2020 showed that 'Indonesia's internet penetration reached $73.7 \%$, with a growth of $8.9 \%$ from 2018 . Indonesian internet users reached around 196.7 million users or $73.7 \%$ of the total population of Indonesia. In other words, at least 07 out of 10 Indonesians have used the internet. Internet use has been evenly distributed throughout Indonesia, where people in Java are the most significant internet users (41.7\%). Almost all Indonesian internet users access the internet via smartphones/mobile phones (95.4\%) and use data packages (quota) from cellular operators (97.1\%). 19.5\% use online for more than eight hours a day! Meanwhile, the main reasons for using the internet are social media (51.5\%), communicating via messages $(32.9 \%)$, playing games (5.2\%), and accessing public services $(2.9 \%)$. In comparison, relatively very few use the internet for business and educational activities (APJII, 2020).

The fact that most people use the internet and digital technology for social media and playing games means that Indonesians tend to surf the internet only for leisure and have not taken advantage of the extraordinary potential of the internet. Therefore, efforts are needed to encourage MSMEs to take advantage of the use of the internet. In other words, Indonesian policymakers need to synergize between the digitalization of MSMEs and the digital society to developing digital entrepreneurship in Indonesia during the Covid-19 pandemic.

However, according to the records of Cooperatives and SMEs, there are 10.25 million SMEs connected to digital platforms today. In short, this figure is still shallow compared to $99 \%$ of the total number of companies operating in Indonesia, where the number of SMEs reaches 64.1 million (Jatmiko, 2020). The Ministry of Cooperatives and SMEs is continuously holding many MSME digitization programs. It should be noted that the digitization program is an essential part of the Transformation Program of the Ministry of Cooperatives and SMEs. Also, the way people consume has changed due to the global pandemic. The trend of digitizing MSMEs is a new habit for the future society.

However, during the Covid-19 pandemic, the use of digital platforms by Indonesian MSMEs has increased significantly. According to a survey conducted by the Ministry of Cooperatives and SMEs in collaboration with IDEA (Indonesian E-Commerce Association), $75 \%$ of the sustainability of MSMEs after entering e-commerce is challenging to maintain in terms of characteristics, after-sales service, and others. In other words, social media is a sector 
for developing entrepreneurship and sustainability in MSMEs (Purwana, Rahmi, \& Aditya, 2017). Meanwhile, based on McKinsey data, e-commerce sales grew 26\%, bringing the total daily transactions to 3.1 million (Catriana, 2020). According to data from the Indonesian ECommerce Association (BPMI Setpres, 2021), 13.7 million Indonesian MSMEs joined the digital ecosystem in May 2021. Even during the Covid-19 pandemic, it has encouraged higher use of social media, which of course, correlates with increased sales transactions SMEs. In other words, it can be said that MSME actors who have succeeded in conducting sales transactions during the pandemic can be said to have succeeded in using digital platforms and social media. In addition, with the development of the digitization of MSMEs, 'Indonesia's digital economy will become the most prominent digital economy in Southeast Asia by 2025.

However, there are three obstacles faced by MSMEs. First, MSME actors are always limited in their product capacity. Even many MSMEs fail in the digital market because they do not meet the needs of the digital market. Second, the absorption and quality of MSME actors are not evenly distributed. The reason is, in this digital market, players have to compete with large companies that switch to using digital platforms during the pandemic. Third, it is necessary to strengthen digital literacy education and human resources for MSME actors (Suwarni, Sedyastuti, \& Mirza, 2019). So far, digital literacy and the quality of human resources for MSME actors are very low, resulting in a less than optimal production of each of their respective superior products. The majority of MSME players want to practice digital e-commerce in business development (Susanti, 2020).

Efforts to develop digital MSMEs require synergy with the digital community, which incidentally is the millennial generation. These Digital societies can be encouraged to be able to participate in developing digital MSMEs with reseller techniques. In this case, the digital community is invited to synergize, especially the millennial generation and generation $\mathrm{Z}$, who are spread across several classifications, namely buzzers, influencers, and followers (Arianto, 2019). The MSME digital development program also relies heavily on government support to facilitate licensing.

As a result, the primary connection of digital MSMEs is better formed. The development of digital MSMEs is in line with the Ministry of Communication and Information government program, which recently launched a digital MSME training program. Ministry of Communication and Information needs these various programs to assist MSME actors in switching to digital platforms.

Because improving digital infrastructure is the key to the growth of MSMEs, this is beneficial for SMEs and is also considered to support other programs such as the Job Creation Law (Kominfo, 2020). Meanwhile, 'Indonesia's digital economy potential could reach Rp 1.8 trillion by 2025, according to Teten Masduki, Minister of Cooperatives and Small and Medium Enterprises (Buana, 2020). Therefore, MSME actors must immediately implement digital for the development of business units and ensure that outside products do not exploit this huge market potential.

Therefore, MSME actors need to pay attention to three things when they want to enter the digital realm: production quality, production capacity, and digital literacy. MSME actors need to focus on these three factors so that open businesses in the digital sector can complement each other and have long-term prospects. MSMEs need a digital development strategy to provide IT infrastructure, production processes, and market expansion in the short, medium, and long term. Small and medium enterprises are competitive and can improve their performance (Slamet, Nainggolan, Roessobiyatno, Ramdani, \& Hendriyanto, 2016). 
Furthermore, the growth of MSME digitization is not limited to digital marketing. However, the same is true for digital financial payments. So that this step can help MSME actors who have been an obstacle to paying off their debts digitally, then this step will quickly improve the quality of MSMEs in Indonesia. In the end, the growth of digital MSMEs will help Indonesian MSMEs not only become a digital foundation but also last longer in the digital market. Therefore, mitigation and recovery solutions are needed that inspire demand and spur digital platforms to expand partnerships. In addition, cooperation is needed to use innovation and technology that helps improve product quality and competitiveness in product processing, product processing, and marketing (Handoko, 2020).

This research will further elaborate on the development of digital-based SMEs during the Covid-19 pandemic. Several previous studies have reviewed that MSME actors have switched to using digital technology, including social media, for the development of MSMEs in Indonesia (Anggia \& Shihab, 2018; Bakhri \& Futiah, 2020; Idah \& Pinilih, 2019; Setyanto, Samudro, Pratama, \& Soesilo, 2015; Sumarni \& Melinda, 2020). This research is more about an effort to emphasize the digital-based MSME development model during the Covid-19 pandemic. This development also includes utilization, marketplace, social media, and various other supporting applications. In the end, the development of digital MSMEs during the Covid-19 pandemic has saved the fate of MSMEs in Indonesia, which then invites questions; How is the process of developing digital SMEs during the Covid-19 pandemic? The limitations in this study are only about the role and implications for the development of digital MSMEs to build and save the MSME ecosystem during the Covid-19 pandemic.

\section{Research method}

This article uses a literature study with a library research approach by observing and analyzing all information about the research topic. A literature study is used to collect various data in depth through various literature books, notes, magazines, journals, other references, and detailed information and data from the results of previous related studies. Literature study can provide answers and relevant theoretical foundations to obtain answers, and theoretical foundations on the problems raised will be studied (Zed, 2008). Twenty-five articles were reviewed in this study from Sinta (Science and Technology Index) and Google Scholar.

This library research procedure is used to develop concepts and descriptions regarding the Development of Synergistic between Digitalization MSMES and Digital Society in Indonesia. The following are the steps in library research according to Zed (2008): Having a general idea about the research topic; Finding information that supports the topic; Reinforcing the research focus; Finding and finding the necessary reading materials and classifying reading materials; Reading and make research notes; Reviewing and re-recording reading material; and finally, Classifying again reading and writing material.

In this study, the main topic for collaboration is developing a digital model for SMEs during the Covid-19 pandemic. Therefore, in the era of the digital economy, we can see that the development of digital SMEs is an alternative to developing and, at the same time, saving MSMEs. Several steps will be taken in the article that puts forward the literature study model: First, researchers observe and analyze phenomena about the object of research. Second, determine the research focus based on the information obtained from the literature review. Third, the data sources collected as information or empirical data from books, journals, research reports, and other literature can provide new research fields. In this way, it helps the researcher to identify various variables related to the research topic. Fourth, examine various sources to get maximum results to find new ideas related to research topics. Finally, analyzing different 
research notes from diverse literature to then get a conclusion compiled in the form of a research report with the applicable writing systematics. Thus, the literature study method can combine the findings of the same theme as preliminary studies with contemporary studies (Zed, 2008). Thus, verification of previous studies can find elements of novelty in further research.

\section{Discussion}

\subsection{Digital economy ecosystem}

The challenges faced by MSMEs in Indonesia are diverse because they are closely related to the entrepreneurship ratio in Indonesia, which is only 3.5\%. Therefore, improving the quality of MSMEs is an absolute must so that in the future, it can create conditions of ease of doing business. It should be noted that MSMEs have played an essential role in strengthening the Indonesian economy. Based on the experience of the Indonesian economic crisis, MSMEs have become one of the fundamental pillars of the Indonesian economy. Meanwhile, the MSME sector, which was so stagnant during the Covid-19 pandemic, is expected to continue to survive through a digital transformation strategy. In September 2020, according to BPS data (Avriyanti, 2021), the conditions faced by MSMEs during the Covid-19 pandemic turned out to be only $45 \%$ of SMEs who were only able to survive for three months; the rest could not survive.

Therefore, as part of efforts to develop digital MSMEs, one of the alternatives carried out by the Ministry of Cooperatives and SMEs is to invite young innovators to support the MSME digitization program through the MSME Digital Hero program. This program aims to enable MSME actors to increase sales and survive with the support of the digital ecosystem during the Covid-19 pandemic. The Ministry of Cooperatives and SMEs have a strategy for developing SMEs' digitization through four stages. First, increasing human resources so that SMEs can prepare MSME business actors and strengthen their capabilities. The quality of human resources is the most critical factor in fostering MSMEs in the digital era. Many MSME actors admit many obstacles in using digitalization and social media due to a lack of knowledge (Purwana et al., 2017).

Second, intervene in the improvement of MSME business processes and implement them in several programs. In addition to marketing techniques, knowledge about the importance of financial literacy is also needed for MSME actors. Financial literacy can enable MSME actors to systematically manage business units, especially those dealing with debt and receivable issues. This financial literacy also includes the accounting process of MSMEs. Most MSMEs in Indonesia do not register according to the Financial Accounting Standards for Entities without Public Accountability. After all, there are obstacles to their implementation. This obstacle is caused by the lack of quality of financial reporting for MSMEs (Mubiroh \& Ruscitasari, 2019).

Third, expanding market access encourages synergy between the Ministry of Cooperatives and SMEs with the Government Goods Service Procurement Policy Institute so that MSME actors can become vendors of government procurement of goods and services. Fourth, glorify the local heroes of SMEs. This local hero of MSME players will become lighter, empowered, have a strong brand, and overall ability to aggregate Micro and Small businesses to anchor to digital platforms or international markets.

In addition, during the Covid-19 pandemic, to revive this condition, mitigation and recovery solutions are needed, namely by creating stimulus on the demand side and encouraging digital platforms to expand partnerships. During the current Covid-19 pandemic, the Ministry of Cooperatives and SMEs must continue to emphasize various strategies for the digital development of SMEs. However, the next step is to encourage the participation of stakeholders, 
namely companies and universities, in this profile so that they can work with SMEs to implement digital transformation quickly. Millennials who facilitate the digital transformation of MSMEs can participate in digital entrepreneurship. That way, in the end, it can create young innovators, then create various forms of startups based on MSME problems in the Indonesian context. The presence of MSME-based startups can create synergies that can accelerate the digital transformation of MSMEs. After that, the institutionalization of 'Indonesia's digital economy will be even stronger.

\subsection{Digital technology for MSMEs}

Technology is a scientific method that achieves the practical goals necessary for human existence and comfort. Etymologically, the etymology of the word technology is "techne". It refers to a set of logical principles or methods, knowledge of a particular technique, principle, method, and the art involved in making something. Digital is a Greek word that comes from the word Digitus, which means fingers. Due to the pandemic, people need to do something out of the ordinary. The most fundamental change during the Covid-19 pandemic was partially and universally interpreting development, including full human development - the mindset of people starting to change themselves into care by mastering digital technology. The Covid-19 pandemic does impact the emergence of MSMEs and cooperatives. However, on the other hand, there is an excellent opportunity to utilize information technology to optimize sales or use the internet to create new products.

In Indonesia, MSMEs are mobilized to take advantage of digital technology by setting up online sales. However, many people out there have not touched the internet, and they sell things online. According to Law Number 20 of 2008 concerning MSMEs (OJK, 2017), microenterprises are commercial and manufacturing companies owned by individuals and organizations that meet the SME standards required by law. SMEs are efficient and independent economic enterprises run by individuals or legal entities that are not subsidiaries or partners owned, controlled, or partially owned by SMEs. Small businesses are regulated by law. SMEs are independent, efficient, and economical businesses managed by individuals or legal entities, not subsidiaries or branches of companies that are owned directly or indirectly. Large companies with total capital or annual sales are required by law.

The Covid-19 pandemic has had a substantial economic impact and requires predictable and robust action to contain it. Stimulus measures need to be taken to prevent bankruptcy from mitigating the economic impact, especially among the vulnerable and the business world. Digital technology is expected to affect productivity. Optimizing the use of digital technology as part of adapting to the impact of Covid-19 can also be one way to overcome poverty. MSMEs are one of the 'country's economies that have survived this pandemic and are expected to revive the global economy.

\subsection{The need for creative content}

The growth of digital-based MSMEs in Indonesia is noteworthy, especially in terms of creative content. Content is the mainstay of competition in the digital realm because in the digital era. Without creative content, the growth of digital-based SMEs will inevitably be difficult to find significant results. In this case, the innovative content design must be pursued by MSME actors themselves through various additional training courses. MSME actors must be encouraged to understand the Character of the digital world, especially social media. In social media, content is the main product or service that can attract 'consumers' attention. Therefore, MSME actors need to understand the creative content of digital marketing. Several studies have shown that creative content can attract much attention from the digital community (Arianto, 2015). 
The growth of MSMEs in Indonesia is constrained by many factors, especially in marketing products and services. These barriers range from product management to marketing techniques. Especially in the context of the Covid-19 pandemic, MSME actors must be able to make changes in the digital world, especially in digital marketing. Indonesia still has many MSME products and services to display finished products. As a result, the products and services offered do not have a value that attracts 'consumers' attention. However, various assistance through training in packaging products and services can attract 'consumers' attention. In short, it takes technology to create creative content for brands and product packaging. Therefore, it can attract 'consumers' attention when marketing through social media and marketplaces.

The next obstacle faced by MSMEs is limited marketing costs. In this case, the cost of promoting a product or service. In this case, MSMEs can benefit from social media marketing and automatically sell digital products using innovative content packages. However, this digital marketing also requires knowledge of using applications that support marketing aspects. For example, using the E-MSME application as a marketing application for MSME products is a prospective step to improve the Indonesian economy (Amelia, Prasetyo, \& Maharani, 2017).

Therefore, MSMEs must meet specific requirements in order to produce creative content. MSME actors need to learn photography techniques, videography and compose interesting sentences on social media. These three things must be fulfilled by MSME actors so that the public can know their products and services. The first is photography techniques. In this case, every SME needs to take photos of its products and services in an attractive and high-resolution way. Learning good photography techniques will create attractive products and services when they are posted on social media.

Therefore, there is always a need for a third party to provide much training for MSME actors to create attractive product photos. Second, videography techniques. MSME actors must also create video content because creative video content has a higher value than photo and image content. Some studies say that videos will have a higher share value (Arianto, 2019). Finally, the arrangement of sentences is made as attractive as possible. In this case, the caption that appears on social media is essential to attract public attention. Therefore, learning is needed for MSME actors to learn to write well so that the sentence structure becomes more interesting with copywriting.

Various training was part of the digital MSME development training, especially in producing creative content (Photojournalism, Creative Videos, Creative Writing), including building branding logos and good packaging. In addition, MSME actors must have digital marketing training (digital marketing) on all available social media. MSMEs are expected to increase sales through digital media and direct sales and help MSME partners increase their competitiveness (Intan, Revia, \& Erwita, 2019).

\subsection{Building synergy between digital MSMEs and digital society}

In the digital era, the digital community cannot separate the role of social media in particular. Because these digital societies will determine the success of a product and service, it will become a public concern. In this case, digital society is the identity of people on social media. In the digital world, there are several categories. Digital societies are users of social media platforms in digital reciprocity in cyberspace. The digital society is also divided according to the classification of the activity level of using social media. This classification forms several terms according to their role in expanding and disseminating digital messages or content.

The roles that exist in digital society are buzzers, influencers, and followers. In social media, a buzzer is defined as an account that is always active to disseminate, campaign, and 
deliver digital messages and content to other Digital societies to influence or improve messages or content. Influencers are social media accounts that have a powerful impact on their followers to encourage and influence followers to do what they want. According to Character, followers are social media accounts that follow the behavior of influencer and buzzer accounts. These three digital community actors must also understand MSME business actors in the development of social media marketing. In addition, in the evolution of digital-based MSMEs, MSME actors must synergize with the digital community by posting creative and innovative content.

Through presenting creative content, it can automatically attract the attention of the digital community to be able to participate in disseminating their products. That way, this synergy will make the products and services offered by MSMEs widely known by actors in the digital community. In addition, the synergy developed is by using reseller techniques. This technique invites digital people who come from generation $\mathrm{Z}$ to participate in reselling products produced by MSMEs. The reseller technique by the millennial generation will be a perfect marketing channel, and the millennial generation also has a wide range of friendship nodes. With this synergy, it is hoped that the marketing of digital MSME products will increase. This reseller technique must also involve marketplaces such as Lazada, Tokopedia, Bukalapak, Shopee, and other marketplaces.

So that through this marketplace marketing media, it will open up more opportunities to promote MSME products more broadly in the digital community. The last technique is to collaborate with digital communities, especially Generation Z, to promote MSME products and services. This technique allows millennial Digital Society to provide testimonials for MSME products through their respective social media. With this testimonial technique, which is then distributed through every social media of each digital community, at least it can be one of the promotional media. This promotional media means that by involving the digital community more and more to provide testimonials, the greater the chance that consumers will accept products from digital MSMEs in Indonesia. Because without the synergy between MSMEs and the digital community, it will be difficult for MSME business actors to offer their products quickly on social media. Therefore, knowledge in recognizing digital community actors to techniques to go viral. This knowledge must be obtained independently by MSME actors, mentoring, and various training by third parties or independently.

\section{Conclusions}

Due to the spread of Covid-19, MSMEs (Micro, Small, and Medium Enterprises) have stagnated until several shops have closed. This condition causes new habits to develop and the implementation of health protocols that affect the decline in people's purchasing power. Against the backdrop of the Indonesian economy, the transmission of Covid-19 can eventually spur the formation of a new ecosystem, digital entrepreneurship. In short, this ecosystem has encouraged MSME actors to start their transformation into the digital realm. However, the government has made efforts to promote digitalization programs for Indonesian MSMEs. These efforts to encourage digitalization may be due to the adaptation of MSME actors to social media and marketplaces in digital marketing. The role of social media platforms is also the main focus of MSME actors. In addition, MSME actors are starting to adapt using various supporting applications such as digital financial platforms. The digital transformation of MSMEs during the Covid-19 pandemic can finally make MSMEs re-develop their businesses. Therefore, during the Covid-19 pandemic, digital MSME growth can still exist because it can be an alternative to saving the MSME sector. 
The efforts to develop digital SMEs must be supported by the local government and the Ministry of Cooperatives and SMEs. Because MSME actors still need a lot of support, guidance, and capital, which incidentally comes from the government during the Covid-19 pandemic. If there is synergy between MSMEs, the government, and other supporting stakeholders, the MSME digital transformation process will inevitably run perfectly. So that the 'government's target to increase digital-based MSMEs can be realized immediately. In addition, the development of digital MSMEs after the Covid-19 pandemic must also be a top priority for the government and all stakeholders so that the digital economy ecosystem in Indonesia continues to run well.

The development of digital MSMEs will also contribute to strengthening the digital entrepreneurship ecosystem in Indonesia. In the end, this article argues that the development of digital MSMEs during the Covid-19 pandemic can be an alternative for developing MSMEs in the era of the digital economy. In addition, the development of digital MSMEs is also one of the strategies to save MSMEs so that they can still exist during the Covid-19 pandemic. Furthermore, various MSME digitalization development programs can accelerate the digital transformation process in 'Indonesia's digital economy ecosystem, making MSMEs compete in the international arena.

\section{References}

Amelia, M. N., Prasetyo, Y. E., \& Maharani, I. (2017). E-UMKM: Aplikasi pemasaran produk UMKM berbasis android sebagai strategi meningkatkan [IndonesiaE-UMKM: Androidbased MSME product marketing application as a strategy to improve Indonesia]. Prosiding SNATIF, 11-16.

Anggia, M. N., \& Shihab, M. R. (2018). Strategi media sosial untuk pengembangan UMKM [Social media strategy for MSME development]. Jurnal Terapan Teknologi Informasi, 2(2), 159-170.

Arianto, B. (2015). Kampanye kreatif dalam kontestasi presidensial 2014 [Creative campaign in 2014 presidential contest]. Jurnal Ilmu Sosial dan Ilmu Politik UGM, 1(19), 16-39.

Arianto, B. (2019). Buzzer media sosial dan branding produk umkm daerah istimewa yogyakarta [Social media buzzer and product branding for the special region of Yogyakarta UMKM]. Jurnal UMKM Dewantara, 2(1), 27-46.

Arianto, B. (2021). Pengembangan UMKM digital di masa pandemi Covid-19 [Development of digital MSMEs during the Covid-19 pandemic]. ATRABIS: Jurnal Administrasi Bisnis, 6(2), 233-247. doi:10.38204/atrabis.v6i2.512

Avriyanti, S. (2021). Strategi bertahan bisnis di tengah pandemi Covid-19 dengan memanfaatkan bisnis digital (Studi pada ukm yang terdaftar pada dinas koperasi, usaha kecil dan menengah kabupaten tabalong) [Business survival strategy in the midst of the Covid-19 pandemic by utilizing digital business (Study on SMEs registered with the Cooperatives, Small and Medium Enterprises Office of Tabalong Regency)]. Jurnal PubBis, 5(1), 60-74.

Bakhri, S., \& Futiah, V. (2020). Pendampingan dan pengembangan manajemen pemasaran produk umkm melalui teknologi digital di masa pandemi Covid-19 [Assistance and development of MSME product marketing management through digital technology during the Covid-19 pandemic]. Jurnal Loyalitas Sosial: Journal of Community Service in Humanities and Social Sciences, 2(2), 59-70. 
Balassa, B. (2013). The theory of economic integration (Routledge revivals). London, UK: Routledge.

BPMI Setpres. (2021). Government Targets 30 Million MSME Actors to Join the Digital Ecosystem by 2024. Retrieved April 10, 2021 from https://www.presidenri.go.id/siaranpers/pemerintah-targetkan-30-juta-pelaku-umkm-tergabung-dalam-ekosistem-digital-pada2024/

Buana, G. (2020). Digital Economy Potential IDR 1,800 T. Retrieved April 10, 2021 from https://mediaindonesia.com/economy/366834/potensi-economy-digital-rp1800-t

Catriana, E. (2020). Minta UMKM percepat adopsi digital, menteri teten: Jangan sampai pasar kita diambil luar [Ask SMEs to accelerate digital adoption, minister Teten: Don't let our market be taken outsider]. Retrieved March 10, 2021, from https://money.kompas.com/ $\mathrm{read} / 2020 / 12 / 03 / 192200426 /$ minta-umkm-percepat-adopsi-digital-menteri-teten-jangansampai-pasar-kita

Elia, G., Margherita, A., \& Passiante, G. (2020). Digital entrepreneurship ecosystem: How digital technologies and collective intelligence are reshaping the entrepreneurial process. Technological Forecasting and Social Change, 150, Article 119791.

Giones, F., \& Brem, A. (2017). Digital technology entrepreneurship: A definition and research Agenda. Technology Innovation Management Review, 7(5), 44-51.

Handoko, L. T. (2020). Membangkitkan UMKM di masa pandemi dengan inovasi dan teknologi [Generating MSMEs during the pandemic with innovation and technology]. Retrieved March 10, 2021, from http://lipi.go.id/siaranpress/membangkitkan-umkm-di-masapandemi-denganinovasi-dan-teknologi/22212

Idah, Y. M., \& Pinilih, M. (2019). Strategi pengembangan digitalisasi UMKM [MSME digitalization development strategy]. Prosiding Jurnal LPPM Unsoed, 9(1), 195-204.

Intan, T., Revia, B., \& Erwita, A. (2019). Peningkatan daya saing produsen minuman herbal melalui pembuatan konten kreatif media sosial berbasis pemasaran e-marketing [Increasing the competitiveness of herbal drink producers through the creation of creative social media content based on e-marketing]. Jurnal Komunikasi Profesional, 3(2).

Jatmiko, L. D. (2020). Wow! Nilai ekonomi digital Indonesia 2020 tembus Rp624,2 triliun [Wow! The value of Indonesia's digital economy in 2020 reached Rp624.2 trillion]. Retrieved April 10, 2021, from https://teknologi.bisnis.com/read/20201124/84/1321753/ wow-nilai-ekonomi-digital-indonesia-2020-tembus-rp6242-triliun

KemenkopUKM. (2020). Pemerintah wajibkan kementerian dan lembaga belanja produk di UMKM dengan minimal pagu 40 persen [The government requires ministries and institutions for product spending in MSMEs with a minimum ceiling of 40 percent]. Retrieved April 20, 2021, from https://kemenkopukm.go.id/read/pemerintah-wajibkankementerian-dan-lembaga-belanja-produk-di-umkm-dengan-minimal-pagu-40-persen

Kominfo. (2020). Siaran Pers No. 84/HM/KOMINFO/07/2020 [Press Release No. 84/HM/KOMINFO/07/2020]. Retrieved April 10, 2021, from https://kominfo.go.id/ content/detail/27898/siaran-pers-no-84hmkominfo072020-tentang-peluncuran-gerakannasional-bangga-buatan-indonesia-kitabelakitabeli/0/siaran_pers

Lee, Y. Y., Falahat, M., \& Sia, B. K. (2019). Impact of digitalization on the speed of internationalization. International Business Research, 12(4), 1-11. 
Martin, A. (2008). Digital literacy and the "Digital society." Digital Literacies: Concepts, Policies, and Practices, 30, 151-176.

Mubiroh, S., \& Ruscitasari, Z. (2019). Implementasi SAK EMKM dan pengaruhnya terhadap penerimaan kredit UMKM [Implementation of SAK EMKM and its effect on MSME loan acceptance]. Berkala Akuntansi dan Keuangan Indonesia, 4(2), 1-15.

Nambisan, S. (2017). Digital entrepreneurship: Toward a digital technology perspective of entrepreneurship. Entrepreneurship Theory and Practice, 41(6), 1029-1055.

OJK. (2017). Law Number 20 of 2008 concerning Micro, Small and Medium Enterprises. Retrieved April 10, 2021 from https://www.ojk.go.id/sustainable-finance/id/peraturan/ undang-undang/Pages/Undang-Undang-Republik-Indonesia-Nomor-20-Tahun-2008Tentang-Usaha-Mikro,-Kecil,-dan-Menengah.aspx

Organization for Economic Cooperation and Development (OECD). (2017). Digitalisasi adalah kunci untuk mempertahankan pertumbuhan di emerging Asia, menurut laporan terbaru [Digitalization is key to sustaining growth in emerging Asia, according to latest report]. Retrieved April 20, 2021, from https://www.oecd.org/dev/Press_release_Outlook2018_ Indonesian.pdf

Permadi, D., Shabrina, F., \& Rahyaputra, V. (2018). Menyongsong kewirausahaan digital Indonesia [Welcoming Indonesian digital entrepreneurship]. Yogyakarta, Indonesia: UGM PRESS.

Purnomo, F. (2019). Ladit Program (Lapak Digital): Program ladit (Lapak Digital): Optimalisasi media digital sebagai wadah dalam pengembangan UMKM di madura [Optimizing digital media as a forum for developing MSMEs in Madura]. Jurnal Studi Manajemen Dan Bisnis, 6(2), 89-95.

Purwana, D., Rahmi, R., \& Aditya, S. (2017). Pemanfaatan digital marketing Bagi Usaha Mikro, Kecil, Dan Menengah (UMKM) Di Kelurahan Malaka Sari, Duren Sawit [Utilization of digital marketing for Micro, Small and Medium Enterprises (MSMEs) in Malaka Sari Village, Duren Sawit]. Jurnal Pemberdayaan Masyarakat Madani (JPMM), 1(1), 1-17.

Saputra, D. (2021). Survei BI: 87.5 persen UMKM Indonesia terdampak Pandemi Covid-19 [BI Survey: 87.5 percent of Indonesian MSMEs are affected by the Covid-19 Pandemic]. Retrieved April 20, 2021, from https://ekonomi.bisnis.com/read/20210319/9/1370022/ survei-bi-875-persen umkm-indonesia-terdampak-pandemi-covid-19\#: :text=Bisnis.com\% 2C\%20JAKARTA\%20\%E2\%80\%93

Setyanto, A. R., Samudro, B. R., Pratama, Y. P., \& Soesilo, A. M. (2015). Kajian strategi pengembangan umkm melalui media sosial (Ruang lingkup kampung batik laweyan) [Study of MSME development strategies through social media (Scope of Kampung Batik Laweyan)]. Sustainable Competitive Advantage (SCA), 5(1), 1-18.

Slamet, R., Nainggolan, B., Roessobiyatno, R., Ramdani, H., \& Hendriyanto, A. (2016). Strategi pengembangan ukm digital dalam menghadapi era pasar bebas [Digital SME development strategy in facing the free market era]. Jurnal Manajemen Indonesia, 16(2), 136-147.

Sumarni, T., \& Melinda, L. D. (2020). Media sosial dan e-commerce sebagai solusi tantangan pemasaran pada masa pandemi covid-19 (Studi kasus: UMKM warung salapan) [Social media and e-commerce as a solution to marketing challenges during the covid-19 pandemic (Case study: small and medium-sized breakfast stalls)]. ATRABIS: Jurnal Administrasi Bisnis, 6(2), 163-171. 
Susanti, E. (2020). Pelatihan digital marketing dalam upaya pengembangan usaha berbasis teknologi pada umkm di desa sayang kecamatan jatinangor [Digital marketing training in an effort to develop technology-based businesses for MSMEs in Sayang Village, Jatinangor District]. Sawala: Jurnal pengabdian Masyarakat Pembangunan Sosial, Desa dan Masyarakat, 1(2), 36-50.

Suwarni, E., Sedyastuti, K., \& Mirza, A. H. (2019). Peluang dan hambatan pengembangan usaha mikro pada era ekonomi digital [Opportunities and barriers to micro-enterprise development in the digital economy era]. Ikra-Ith Ekonomika, 2(2), 29-34.

The Indonesian Internet Service Providers Association (APJII). (2020). Laporan survei internet APJII 2019 - 2020 (Asosiasi penyelenggara jasa internet Indonesia, No. 2020) [APJII 2019 - 2020 internet survey report (Association of Indonesian internet service providers, No. 2020)]. Retrieved April 10, 2021, from https://apjii.or.id/survei

Wuryantai, A. E. W. (2004). Digitalisasi masyarakat: Menilik kekuatan dan kelemahan dinamika era informasi digital dan masyarakat informasi [Digitalization of society: Examining the strengths and weaknesses of the dynamics of the digital information era and the information society]. Jurnal ILMU KOMUNIKASI, 1(2), 131-142.

Zed, M. (2008). Metode penelitian kepustakaan (Cetakan 1) [Literature research method (Print 1)]. Jakarta, Indonesia: Yayasan Obor. 